\title{
Prospects for the Development of the Banking Sector of Azerbaijan
}

\author{
Y.F. Veliyeva \\ Azerbaijan State University of Economics, Baku, Azerbaijan \\ https://orcid.org/0000-0002-9758-9469
}

\begin{abstract}
The relevance of the problem of the banking sector development lies in the fact that banks, implementing their economic policy, can ensure continuous sustainable growth of the entire national economy. The study aims to offer long-term proposals for the development of the banking sector of Azerbaijan, which will bring it to the next level. During the research the author used such methods as the study of literary sources, analysis, synthesis, abstraction and special methods. The study presents six major macroeconomic factors that significantly affect the rate of the long-term growth of the banking sector: customer focus, legal framework, new banking technologies, cyber threats, use of the experience of large IT companies, and qualified personnel. The author analyzed the effects of these factors on the long-term growth rate. Recommendations are given on the use of innovation and advanced technologies for the benefit of development, that will allow building an efficient and competitive banking system. Based on the results of the study, the author formulated proposals for improving the banking sector of Azerbaijan that will bring it to the next level. In particular, it is proposed to optimize robotic process automation, namely, to completely revise the existing methods of work, and not just solve problems using robotization. The author concluded that there is a long way ahead towards ensuring the sustainable development of the banking sector in Azerbaijan, which is currently at the beginning of its journey. Further research on this topic will allow a deeper study of digital opportunities and prospects for the integrated implementation of innovation.
\end{abstract}

Keywords: bank; banking system of Azerbaijan; banking sector, innovation; robotization; technologies; customer focus

For citation: Veliyeva Y.F. Prospects for the development of the banking sector of Azerbaijan. Finance: Theory and Practice. 2021;25(1):120-129. DOI: 10.26794/2587-5671-2021-25-1-120-129

\section{Перспективы развития банковского сектора Азербайджана}

Е.Ф. Велиева
Азербайджанский государственный экономический университет, Баку, Азербайджан https://orcid.org/0000-0002-9758-9469

\begin{abstract}
АННОТАЦИЯ
Актуальность проблемы развития банковского сектора заключается в том, что банки, проводя эффективную экономическую политику, могут обеспечить непрерывный устойчивый рост всей национальной экономики. Цель исследования - сформулировать предложения по перспективному развитию банковской системы Азербайджана, которые позволят вывести ее на новый, более продвинутый уровень. В ходе исследования использованы такие методы, как изучение литературных источников, анализ, синтез, абстракция и специальные методы. Выявлено шесть основных макроэкономических факторов, которые в значительной степени влияют на темпы долгосрочного роста банковской системы: клиентоориентированность, законодательная база, новые банковские технологии, киберугрозы, использование опыта крупных IT-компаний и квалификация персонала банков. Проанализировано, как именно эти факторы влияют на темпы долгосрочного роста. Даны рекомендации по использованию инноваций и передовых технологий в интересах развития, что позволит построить эффективную и конкурентоспособную банковскую систему. По результатам исследования автором разработаны предложения по перспективному развитию банковского сектора Азербайджана, которые позволят вывести его на новый уровень. В частности, предложено оптимизировать роботизированную автоматизацию процессов, а именно - полностью пересмотреть существующие методы работы, а не просто решать задачи с помощью роботизации. Автор пришел к выводу, что предстоит длительная работа в направ-
\end{abstract}

(c) Veliyeva Y.F., 2021 
лении обеспечения устойчивого развития банковского сектора Азербайджана, который в настоящее время находится в начале этого пути. Дальнейшее исследование этой темы позволит глубже изучить цифровые возможности и перспективы комплексного внедрения инноваций.

Ключевые слова: банк; банковская система Азербайджана; банковский сектор; инновации; роботизация; технологии; клиентоориентированность

Для цитирования: Велиева Е.Ф. Перспективы развития банковского сектора Азербайджана. Финансы: теория и практика. 2021;25(1):120-129. DOI: 10.26794/2587-5671-2021-25-1-120-129

\section{INTRODUCTION}

The banks, which form the backbone of the country's financial system, act as intermediaries to ensure that savings are taken from those with surplus funds and transferred to public or private institutions with deficits. The transfer of the provided resources to production and profitable areas has a positive effect on the country's economy and adds dynamism to economic development. As in any country, economic, social and political changes affect the characteristics, structure and orientation of the banking sector in our country. The banking sector is expected to continuously evolve to diversify its economic activities, taking into account the effects of globalization and, as a result, to meet the growing funding needs. The banking sector, which is of great importance for the healthy operation of the economy of the country, has become one of the sectors, which responses sensitively to changes in the national economy.

In this context, the crises that have occurred in the country have affected the entire economy and had very negative consequences for the fragile and uncertain structure of the Azerbaijani banking system. As a result of this negative sector, liquidations and mergers took place and new sectorspecific regulations were introduced. The banking sector performance affects all economic units in the country. Thus, it is important to measure and control the performance of the banking sector.

\section{THE BODY OF THE ARTICLE}

Starting from 2018, in banking, it has become relevant to solve a variety of problems that are related to the settlement, the process of updating outdated systems, the introduction of advanced technologies and business models, an increase in competitiveness and customer expectations, taking into account the provision, in this case, the implementation of a new sustainable development strategy. Banks that are able to seize new opportunities will have a chance to gain an advantage and thus be able to balance long-term goals and short-term performance requirements. The next period will be crucial for the banking system in accelerating their transformation into more strategically oriented and technologically advanced financial institutions with flexible operating structures to maintain leadership in a rapidly changing business environment. This transformation is challenging as most banks face a number of hurdles, such as complex and conflicting regulatory requirements, computer systems becoming obsolete, new technologies evolving, new business models emerging, competition intensifying, and customer demands and expectations constantly increasing.

For this purpose, 6 major factors were identified, which to a large extent affect the rate of long-term growth in the banking system:

1 . The need, as a result of any changes, to maintain the principle of customer focus;

2. Relevant changes in the legal framework in accordance with the measures taken;

3. Rational management of technologies to achieve efficiency in banking;

4. Reducing the level of cyber risks to ensure the security and independence of the process;

5. Development of fintech projects and use of the experience of large IT companies;

6. Revision of labor resources in favor of more qualified personnel.

As a result, banks will have to implement the business transformations necessary to ensure the sustainability of their companies along with their operational challenges. Banks need to find the right balance between long-term goals and today's needs. And those who manage to achieve such a balance will gain significant superiority.

Let's consider each of the six factors in more detail.

1. The need, as a result of any changes, to maintain the principle of customer focus.

Long-term sustainable development in banking is only possible if there is a fundamental shift from a product-centered and sales-centered approach to a customer-centered approach, and then refining 
strategies that target relevant markets, customer segments and solutions.

Although the banking industry has changed in many ways over the past few years, most organizations here, unlike other areas, have not redefined their business processes towards customer focus. As digital innovation evolves, banks run the risk of missing out on customer satisfaction monitoring.

After the liquidation and consolidation of a number of banks in Azerbaijan, the remaining banks were constrained to re-examine their showcase techniques and procedures for working with clients. In numerous cases, such choices were driven by administrative necessities instead of an improved understanding of desires of markets and clients. Opposite to desires, not all banks pay consideration to client fulfillment.

Fortunately, there are banks that are starting to realize that the improvement of already seen danger to the fintech industry opens up favorable prospects for client benefit by leveraging the involvement of fintech companies and organizing participation with them.

Fintech companies have appeared that they can meet all of their necessities and surpass desires through remarkable client care.

However, the presentation of unused innovation, as a run the show, made a difference to unravel existing issues to some extent. The biggest challenge for most banks is to attain organizational adaptability. To do this, they must improve, change the way individuals oversee and construct vital organizations to create choices that advantage clients over the broader environment of members.

2. Relevant changes in the legal framework in accordance with the measures taken.

Expectations of a significant relaxation of regulation may not be justified. Compliance desires, particularly with respect to reasonable treatment of clients and senior administration responsibility, will stay high. In addition, controllers are anticipated to proceed to actualize requirement observing programs and require more divulgences from banks to test the operational judgment of complex organizations, especially in times of stress.

For banks to achieve operational modernization, it is necessary to integrate compliance objectives in terms of control and responsibility with the bank's vital destinations, counting advancement, operational re-arrangements, chance administration and fetched optimization. In other words, the compliance system must be consistent with the bank's business strategy. Failure to do so could put banks at risk of regulatory breaches and reduced productivity.

Banks should also pay particular attention to regulatory compliance when identifying and managing required changes, both at the individual business unit and corporate level. These changes will require managers to consistently apply standards of due diligence in managing their operations. Regulators are also placing increased demands on senior management accountability.

3. Rational management of technologies to achieve efficiency in banking.

To increase the agility of their organizations, bank CIOs must develop areas within their portfolio of technology assets that provide the bank with a real competitive advantage. Ancillary activities should be outsourced cost-effectively.

Most banks confront the challenges of overseeing innovation assets, which are a mess of frameworks, stages, computer programs and apparatuses, numerous of which are obsolete and require critical assets and capital to keep them running easily. In this respect, updating the center working framework is getting to be a self-evident need for banks. According to ICT Enterprise Insights, conducted by analyst firm Ovum in 2016, nearly 25 percent of the banking sector surveyed worldwide cited modernization as the most important IT trend. ${ }^{1}$

To implement vital changes in their banks and increment effectiveness with negligible disruption to inside frameworks, CIOs ought to guarantee the compatibility of unused innovation arrangements from diverse outside providers. This, in turn, may require a significant increase of the IT budget in banks.

However, money alone is usually not enough. In their quest for simplification, modernization and flexibility of systems, banks must ask themselves three important questions:

1. How will they manage their portfolio of technology assets to maximize business performance?

2. How will the specified level and sort of technology outsourcing be decided (locks in third parties to plan, create and oversee innovation arrangements)?

3. How will they focus resources exclusively on developing those activities that provide a competitive advantage?

\footnotetext{
${ }^{1} 2016$ Ovum ICT Enterprise Insights Survey. URL: https:// www2.deloitte.com/kz/ru/pages/financial-services/articles/ gx-banking-industry-outlook.html (accessed on 12.12.2020).
} 
The growth in the number of technology platforms and technology developers in the market, as well as the development of cloud solutions, have made outsourcing more convenient and affordable. Of course, this practice is not new for banks, but often in order to maintain competitive advantages in the market, it becomes necessary to significantly expand the scope of outsourced functions. Bank technology groups can play a key role in managing the new outsourcing model and maximizing business value.

Of course, outsourcing is not applicable to all core activities - technical support for some activities, for example, in the area of compliance and risk management, should be provided by the internal divisions of the bank.

One example of outsourcing is mission-critical managed services that require specialized technical staff but provide the company with a limited competitive advantage [1]. In addition, external service providers can automate compliance processes, which saves labor - the bank staff only needs to complete the final stage of analysis and prepare reports for regulators.

An outsourcing strategy typically requires a more careful approach to technology developer selection, with a focus on high-quality software and in-depth banking knowledge (such as servicing mortgages or handling demand deposits).

Multifunctional organizations prefer to use "star" models that include numerous connections with third parties in several ranges. They are rebuilding their strategies of contracting with providers and overseeing and directing their exercises appropriately.

Outsourcing can moreover play a basic part in modernizing applications - through optimization, rebuilding, code modifying, or porting to another stage, as well as the capacity to move the stage to the cloud.

4. Reducing the level of cyber risks in order to ensure the security and independence of the process.

Increased interdependence among the participants in the banking ecosystem, accelerated introduction of new technologies and continued dependence on obsolete infrastructure - all these factors contribute to the growth of cyber risks.

Cybersecurity is recognized globally - cyber risk is a priority on the agenda of financial risk managers [2]. Acting ahead of ever-changing business needs and addressing increasingly sophisticated threats from attackers is a top priority for bank executives [2].

This is confirmed by the methods of cyber risk management used by many banks now. Many banks employ qualified cybersecurity professionals in their cybersecurity divisions.
However, cyber risk is becoming more complex, and the impact of such risk is often not fully understood and cannot be accurately determined. Thus, there is still much work to be done by banks to implement mechanisms to proactively monitor cyber risks in their operations on a progressing premise. It begins by building a solid culture of due tirelessness all through the organization and understanding cybersecurity as a key factor in creating trade forms, techniques and imaginative arrangements.

As the transformations taking place in many banks are largely driven by technological advances, banks need to analyze and manage cyber risks in all aspects of the changes taking place - whether it is modernizing legacy systems or introducing new technologies. Banks have numerous benefits from paying close attention to cyber risk and understanding its importance in almost all aspects of their business. This approach allows companies to shorten the time it takes to enter new markets, increase their resilience and meet market demands, which is what is meant by organizational flexibility. In short, in order to increase organizational flexibility and efficiency, banks should consider cyber risk as a primary factor in their decision making.

5. Development of fintech projects and use of the experience of large IT companies.

Customer-centric fintech companies remain at the forefront of banking innovation. In this circumstance, banks have a few technique choices. They can begin rehashing the activities of fintech companies, make comparative imaginative arrangements, connected with them (whereas losing their competitive advantage), or follow a coordinated methodology based on their capabilities and showcase position.

In spite of the reality that fintech companies have found their specialty within the managing an account division, numerous will concur that they "have not been able to drastically change the conditions of competition" [3]. Clearly, it is as well early to say that fintech companies and other non-banking organizations will permit buyers to totally desert mediators. Huge legacy players are likely to preserve their showcase administration due to the taking after three components that proceed to work for them:

1) administrative limitations anticipating section to the market;

2) customers' normal hesitance to alter something;

3) the accessibility of adequate capital to secure, build up participation or duplicate the victory of fintech companies.

However, it ought to be recognized that inventive arrangements made by fintech companies take client 


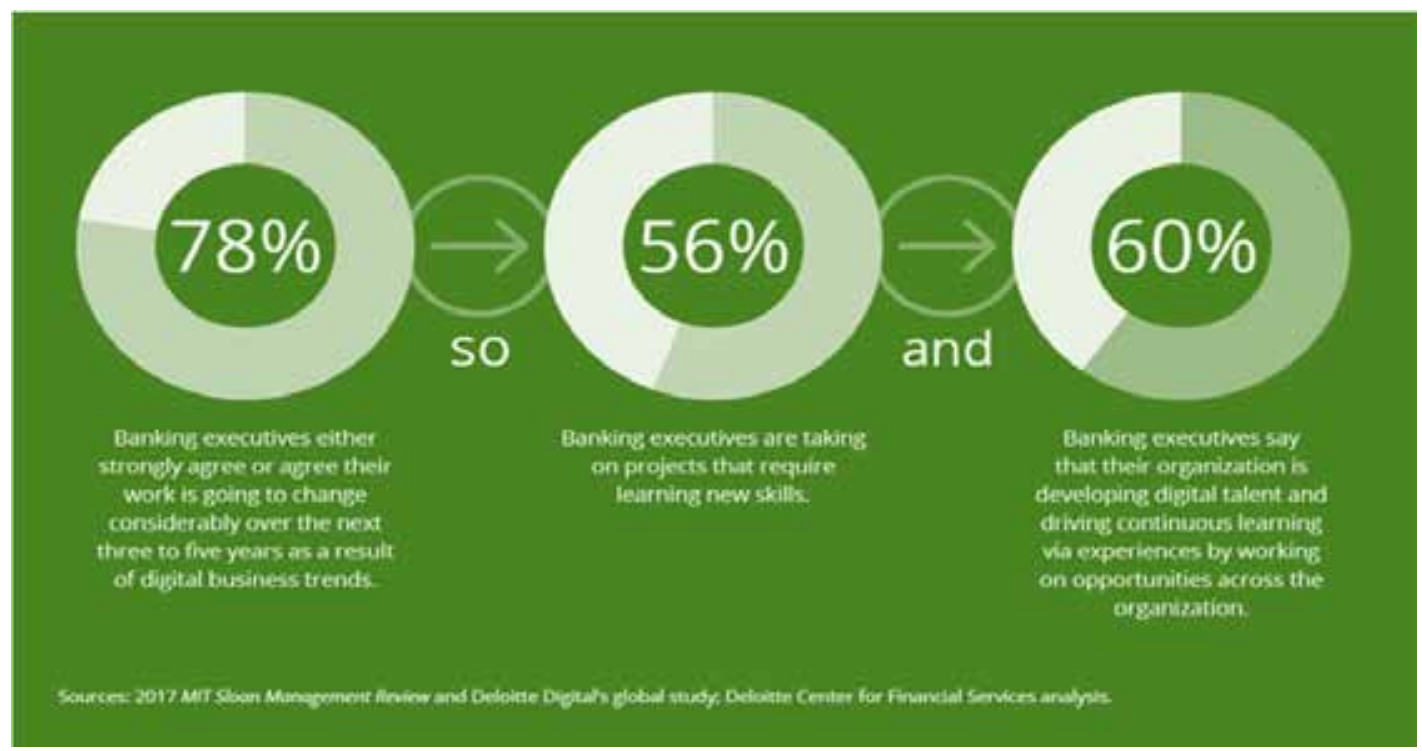

\section{Fig. 1. Modular Learning Based on Artificial Intelligence Technology in Singapore}

Source: 2017 MIT Sloan Management Review and Deloitte Digital's global study: Deloitte Center for Financial Services analysis. URL: https://www2.deloitte.com/kz/ru/pages/financial-services/articles/gx-banking-industry-outlook.html (accessed on 12.12.2020).

benefit to a modern level [3]. But this improvement in fintech organizations and other non-banking companies within the money holding division is most likely indicative of a change in the money holding system itself.

Banks, using the experience of fintech companies, will be able to revise their competitive strategies. As fintech and other non-traditional banking providers embrace different areas of banking (lending, payments, stock trading, high net worth, etc.), traditional banks must compare themselves to what they perceive to be the best at its segment in terms of features and solutions. This broad view of the competition will allow them to become more resilient to future threats.

Banks can develop a more differentiated approach to working with fintech companies, considering their impact on each business function separately (including operations, finance and marketing) [4]. As a result of all these actions, traditional banks will be able to increase their capacity to develop solutions that can meet the needs and desires of both existing and potential customers.

6 . Revision of labor resources in favor of more qualified personnel.

Banks should rethink their talent strategies in light of the changing working conditions caused by the increasing level of automation and ethno-cultural diversity of the workforce.

There is no doubt that automation is rapidly transforming business processes, and advances in technologies such as quantum computing are likely to accelerate these changes. It would seem natural, given the inevitably increasing volumes of automation, to ask the question of what impact it will have on workplaces [5], however, the banking industry has already gone through a similar stage [6]. For example, when the introduction of ATMs began, it allowed banks to free cashiers from the technical function of processing transactions and reorient them to selling banking services and providing advice to customers [7].

In addition, the workforce is expected to become more ethnically and socioculturally diverse in the future. In addition to permanent employees and contractors, it is likely that freelance specialists will appear, interacting with several banks at once; developers of new fintech services and services and even robots that will work together with people [8].

As a result, it can be expected that in arrange to realize victory in this technological world, a bank as it were has to have specialized masters on its staff, but this approach would be short-sighted - the significance of interpersonal abilities ought to not be thought little of. Banks ought to proceed to way better adjust company procedure with worker values through corporate social duty, natural, community and corporate governance initiatives.

Only $17 \%$ of CEOs around the world, working in various sectors of the economy, not to mention the banking sector, when responding to the survey "International Trends in Human Capital", report their readiness to manage a diverse workforce [9].

According to a joint think about by MIT Sloan Management Review and the universal division of 


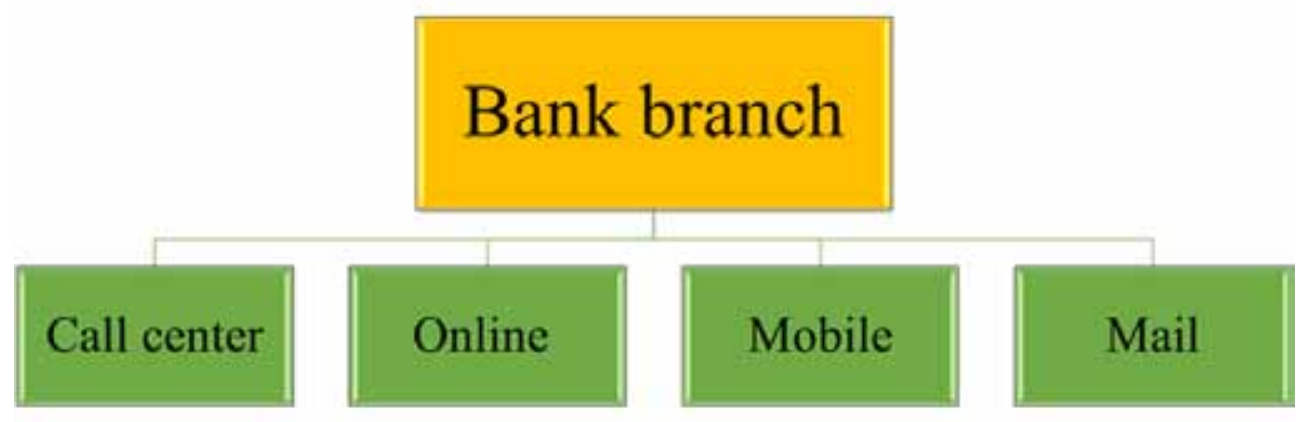

\section{Fig. 2. Banking model of the past}

Source: Forecast of the banking sector development. URL: https://www2.deloitte.com/kz/ru/pages/financial-services/articles/gxbanking-industry-outlook.html (accessed on 12.12.2020).

Deloitte Digital, in arrange to work successfully in an advanced environment, bank workers will create modern aptitudes and capacities (Fig. 1) [10]. A great case in this respect is DBS Bank in Singapore, which has committed 20 million dollars to prepare its representatives in computerized managing an account and innovation development. Secluded preparing takes put concurring to uncommonly planned educational modules on an e-learning stage based on counterfeit insights innovation. ${ }^{2}$

As part of the upcoming transformation, banks will need to create a new collaborative and level playing culture and move towards a more coordinated approach to work at all stages of the working process - from hiring to retirement - taking into account customer satisfaction. This new digitallybased approach, will create the necessary work-life balance for employees and define work objectives they should strive for.

Banks need to consider the six main factors when shaping their strategies to ensure sustainable development in the long term. It is believed that there is a long work ahead in this direction, and the sector is currently at the beginning of its journey.

To harvest the benefits of versatile selection, banks have to change their client procurement methodologies, item portfolios and benefit conveyance models. As before long as financial development strengthens, it is essential to fix financial arrangement. Targeting the correct gathering of people through modern information analytics, making the foremost compelling item

\footnotetext{
${ }^{2}$ DBS to Invest SGD 20 Million Over Five Years to Transform Employees Into Digital Workforce, in Support of Singapore's Aim to Be Smart Financial Centre. Press release. August 21, 2017. URL: https://www.dbs.com/newsroom/DBS to invest SGD 20_million_over_five_years_to_transform_employees_ into_digital_workforce_in_support_of_Singapores_aim_to_be smart_financial_centre (accessed on 12.12 .2020$)$.
}

offerings, and advanced client intuitive with the bank can help lower financing and store costs. Such a compelling technique can be imperative since the liquidity rules presented within the wake of the emergency, in specific the least liquidity prerequisites, might lead to cost wars for retail stores.

This is important to indicate the growing advantage of mobile banking. It is gradually replacing the physical office as the main point of obtaining banking services, providing an even higher level of interaction than using Internet banking (Fig. 2) [11]. The use of mobile technology also comes to the fore at key stages of the customer life cycle, in particular when working with customers from key demographic groups - according to the recent Deloitte study [12] generation $\mathrm{Y}$ and mobile banking users are likely to demand more account opening opportunities.

However, it would be shortsighted to consider mobile technologies only as another communication channel, because they not only improve the quality of customer service but also contribute to the effectiveness of other channels of interaction with the customer (Fig. 3). For example, Umpqua Bank is currently testing a pilot project to implement software that allows employees in the bank's offices to provide banking services to customers via digital communication channels [13].

Expanding customer engagement through mobile channels can help banks address specific compliance issues. Banks can speed up compliance or reduce costs if customers agree or validate data using a portable application. Providing discounts or rewards can act as a motivating force. A customerrecognizable application based on face recognition technology may be used to assist customers and reduce costs of establishing connections with modern customers [14].

Achieving all of this will require more flexible service delivery models, of which mobile is a key 
element, but they could significantly narrow the gap if they double their digital transformation efforts. For example, large retail banks in Europe and Asia have gone much further on these issues and are creating radically new business models that can significantly change the existing market. Obviously, the main driver of these changes is regulation - the second European Union Payments Directive (PSD 2) in Europe and the Open Banking Standard in the UK, in particular, establish completely new rules for obtaining and using customer data, and also reduce barriers to market entry [15]. As a result of these changes, banks and fintech companies are rethinking their approaches to using data and introducing new models of interaction with customers in the new digital reality.

Successful digital transformation usually depends on consistency of administrative methods, a choice of innovation, and management adjustments. In an effort to adapt to such extreme changes, banks are making key choices. Indeed, the most popular banks like Goldman Sachs [16], are focusing their efforts on retail and building advanced departmental systems to serve private clients while promoting their competitive account management services.

However, without revising and optimizing business processes, digitalization can be counterproductive. Thus, robotic process automation is likely to gain popularity, but when implementing this technology, it is important to remember that in order to overcome inefficiencies, it is necessary to completely revise existing ways of working, and not just solve problems with a robot. Blockchain technology is expected to gain widespread acceptance, especially in trade finance and corporate payments. This is naturally due to its ability to eliminate duplication and errors in multilateral transactions. For example, seven large banks in Europe have already partnered with IBM to create a blockchain platform for cross-border transactions in the SME segment [17].

High-tech user platforms are designed to help banks cross-sell paid services more efficiently. Using data lakes in banks to store customer information will allow sales professionals to receive the necessary information using a digital interface right at the meeting with a client. These digital tools, which provide access to data from adjacent business units, can enable junior bank employees to work directly with customers without involving more experienced colleagues, and also reduce the number of participants in the service delivery process. All this, in turn, will allow banks to reduce operating costs.

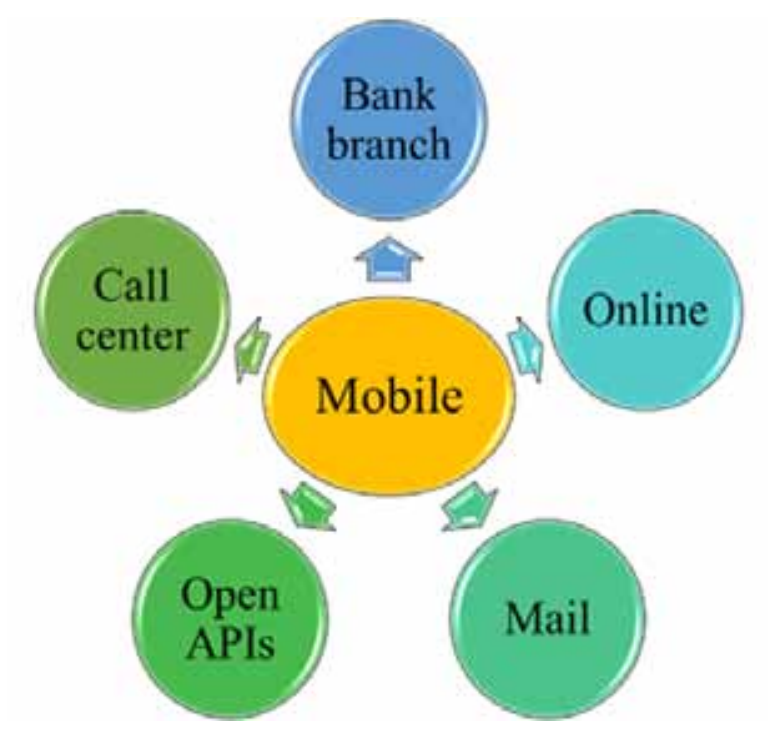

\section{Fig. 3. Banking model of the future}

Source: Deloitte Center for Financial Services. URL: https://www2. deloitte.com/kz/ru/pages/financial-services/articles/gx-banking-industry-outlook.html (accessed on 12.12.2020).

Automation and artificial intelligence are changing many of the competitive edge factors in capital markets - when dealing with customers and supporting transactions - which, in turn, have significant indirect impacts on the operations, talent models and business strategies of market participants. The introduction of innovative technologies, especially cognitive automation technologies, in customer service departments can help improve efficiency and create new sources of growth. Operating units will be able to expand the sources of income and increase their stability by dividing the costs of settlement and clearing operations among all parties to the transaction.

Increasingly, banks are adopting smart automation solutions to improve the efficiency of client offices and new products. For example, Goldman Sachs has implemented robots for trading small batches of corporate bonds so traders can focus on more profitable transactions [18]. UBS uses artificial intelligence technologies to develop an innovative "adaptive strategy" offering that adapts strategy to customer requirements [19]. Sophisticated predictive analytics applied to transaction data enable bank employees to anticipate customer expectations.

These technologies, along with others such as blockchain, are also driving changes in the activities of the controlling and operating divisions of banks. However, much remains to be done. These functions may need to be outsourced so that infrastructure and operations are managed by a third party, as 
capital markets are too costly for many companies due to reduced sources of revenue. It is possible to improve the management efficiency of such companies, for example, by attracting specialized suppliers of technological solutions.

Banks' ability to stay ahead of these trends can be key to the success and stability of their business models. The shift to electronic trading in the high-margin segment such as interest rate swaps, increased price transparency and new reporting requirements could lead to increased pressure on margins.

Of course, the driver of all this innovation in payment services is the explosive growth of e-commerce. However, live sales are still relevant, and an effective strategy for improving the quality of customer service must be built on the principle of omnichannel.

It is likely that well-informed companies with flexible business models, or companies that can quickly copy new solutions from other market participants and implement strategies that allow them to quickly enter the market, will be able to operate in this rapidly changing world of payment services.

At this time, the transition to a non-cash form of payments is being actively carried out, which accelerates economic growth and the development of the digital economy. Commercial banks in Azerbaijan during COVID-19 were forced to switch to a new remote form of service. Such a transformation of the economy through the banking system can give good results in the near future. Among the main problems in the process of providing banking services in the context of the digitalization of the economy, only possible problems with the Internet or electricity supply stand out, there are no other serious obstacles in this process [20]. The process of formation of state policy from the point of view of innovative development is observed. This can make it possible to form positive agenda from the point of view of the balance of the domestic economy since at present the problems associated with the balance of economic development are considered urgent in the world economy. ${ }^{3}$

Another important problem of the banking sector in Azerbaijan is high bank interest rates. The high percentage of banks in the country on loans causes

\footnotetext{
${ }^{3}$ The development of an innovative economy in Azerbaijan was discussed. URL: http://news.unec.edu.az/ekspert-reyi/6980azerbaycanda-innovasiya-tutumlu-igtisadiyyatin-inkishafimuzakire-olunub (accessed on 22.12.2020).
}

discontent among the population. Despite the fact that the topic has repeatedly turned into an agenda and a number of steps have been taken, the problem has not yet been resolved. At the moment, consumer loans in Azerbaijan are provided at an interest rate above 20 , which seems to the citizens of the country to be completely unprofitable. Commercial banks are the reason for such high interest rates on loans. In fact, banks should not be interested in high interest rates, since high interest rates in the future may increase the risk of loan defaults and complicate the bank-client relationship. Moreover, in modern conditions, during COVID-19, when the normal activities of many areas have been suspended, this problem has become even more urgent. As a result, the commercial bank itself loses, so the country's banks are advised to lower interest rates to single digits. Currently, the Central Bank of Azerbaijan is working on a draft of a new law on the banking system. After the adoption of this law, the situation with bank interest is expected to improve. On the other hand, in our opinion, it is considered mandatory to prepare a new conceptual state program for banking. It is believed that the use of simple methods and foreign practice will solve the problem of high interest rates. High interest rates mean expensive homes, cars, equipment. Bank loans affect all areas of the economy. Most companies sell products and other services precisely through bank loans, which ultimately, due to high loans, increases the prices of goods and services provided by these companies. If, for example, a farmer receives an expensive loan, accordingly, he will raise the price for his products. As a result, the entire load falls on the consumer. To solve this problem, competition in the banking system is considered mandatory, namely, a competitive environment should be formed between banks. If local banks continue to maintain high interest rates, there will be a need to attract banks with cheap investments from abroad. Banks should make serious changes in their activities and meet new challenges; the system should be formed anew. It is also necessary to create a special structure that will control banks. Despite the fact that a body called the "Chamber for Control over Financial Markets" was created in Azerbaijan, it did not meet the requirements and was liquidated [21].

\section{CONCLUSIONS}

The results of the study can be presented in the form of the following conclusions characterizing the solution to the set goal of the work: 
1. By using different solutions and expanding digital opportunities, banks must ensure that robots provide them with a tangible competitive advantage. Customers will increasingly look to digital experiences to meet their needs.

2. Banks should also focus on data monetization in view of the possible reduction in traditional revenue channels. In addition, investments in data technology and analytics will be required that will use the bank's own unique data to provide broader insights for and about their customers. This in turn will drive further innovation and better business decisions.

3. Beyond technology, evolving talent needs reflect new risks and business opportunities. Highly qualified specialists in the field of building information models and monitoring cyber threats are currently in high demand. Changing customer needs and developing industry mergers are driving the engagement of specialized professionals rather than industry experts (for example, trade specialists who provide service to clients in various businesses).

The advisability of these recommendations is based on the obvious priority of the banking sector. In addition to the fact that banks perform many other functions, they also boost economic growth, while the economic growth of any country improves the social sphere and the well-being of the population.

The modern economy requires unconventional solutions in the banking sector. Modernization and optimization of banking processes, services, improving the quality of service in combination with low distribution costs are key to the successful development of banks in conditions of financial instability.

\section{REFERENCES}

1. Srinivas V., Goradia U., Wadhwani R. Managed services: A catalyst for transformation in banking. Deloitte Insights. Mar. 22, 2017. URL: https://www2.deloitte.com/us/en/insights/industry/financialservices/managed-services-in-risk-management-and-regulatory-compliance.html

2. Hida E. Global risk management survey, 10th edition: Heightened uncertainty signals new challenges ahead. Deloitte Insights. Mar. 02, 2017. URL: https://www2.deloitte.com/us/en/insights/topics/riskmanagement/global-risk-management-survey.html

3. McWaters R.J., Galaski R. Beyond fintech: A pragmatic assessment of disruptive potential in financial services. Geneva: World Economic Forum; 2017. 197 p. URL: http://www3.weforum.org/docs/Beyond_ Fintech_-_A_Pragmatic_Assessment_of_Disruptive_Potential_in_Financial_Services.pdf

4. Eckenrode J., Srinivas V. Disaggregating fintech: Brighter shades of disruption. New York: Deloitte Center for Financial Services; 2016. 30 p. URL: https:/www2.deloitte.com/content/dam/Deloitte/us/ Documents/financial-services/us-fsi-disaggregating-fintech-brighter-shades-of-disruption.pdf

5. Chanjaroen C. Ex-citi CEO says 30\% of bank jobs at risk from technology. Bloomberg. Sept. 13, 2017. URL: https://www.bloombergquint.com/global-economics/2017/09/13/ex-citi-ceo-pandit-says-30-of-bankjobs-at-risk-from-technology

6. Wladawsky-Berger I. As automation anxiety grows, remember we've been here before: Technological advancements bring new opportunities, and many of the same fears. Wall Street Journal. Sept. 01, 2017. URL: https://www.wsj.com/articles/as-automation-anxiety-grows-remember-weve-been-herebefore- 1504281268

7. Srinivas V. The future of automation in the banking industry: What can we learn from ATMs? Deloitte Quick Look Blog. July 19, 2017. URL: https://www2.deloitte.com/us/en/pages/financial-services/articles/ automation-in-the-banking-industry.html

8. Hagel J., Schwartz J., Bersin J. Navigating the future of work: Can we point business, workers, and social institutions in the same direction? Deloitte Review. 2017;(21). URL: https://www2.deloitte.com/us/en/ insights/deloitte-review/issue-21/navigating-new-forms-of-work.html

9. Schwartz J., Collins L., Stockton H., Wagner D., Walsh B. Rewriting the rules for the digital age: 2017 Deloitte global human capital trends. Colombo: Deloitte University Press; 2017. 144 p. URL: https://www2.deloitte.com/content/dam/Deloitte/us/Documents/human-capital/hc-2017-globalhuman-capital-trends-us.pdf

10. Kane G. C., Palmer D., Phillips A. N., Kiron D., Buckley N. Achieving digital maturity: Adapting your company to a changing world. Cambridge: MIT Sloan Management Review; 2017. 31 p. URL: https://www2.deloitte.com/content/dam/insights/us/articles/3678_achieving-digital-maturity/DUP_ Achieving-digital-maturity.pdf 
11. Bolton D. $61 \%$ of people access mobile banking on a regular basis. Applause. Feb. 01, 2017. URL: https://www.applause.com/blog/mobile-banking-adoption-rates

12. Srinivas V., Fromhart S., Goradia U. First impressions count: Improving the account opening process for Millennials and digital banking customers. Deloitte Insights. Sept. 06, 2017. URL: https://www2.deloitte. com/us/en/insights/industry/financial-services/improving-account-opening-process-in-retail-banking. html

13. Crosman P. When your teller is also your digital banker. American Banker. Sept. 21, 2017. URL: https://www.americanbanker.com/news/where-your-teller-is-also-your-digital-banker

14. Qiange Z., Xueqing J. Banks take bold step forward with face tech. China Daily. Oct. 09, 2017. URL: http://www.chinadaily.com.cn/a/201710/09/WS 5a0bf7a5a31061a738405a2b.html

15. Doyle M., Sharma R., Ross C., Sonnad V. How to flourish in an uncertain future: Open banking. London: Deloitte UK; 2017. 36 p. URL: https://www2.deloitte.com/content/dam/Deloitte/uk/Documents/financialservices/deloitte-uk-open-banking-how-to-flourish-in-an-uncertain-future.pdf

16. Gara A. Wall Street heavyweight Goldman Sachs launches its consumer lending platform Marcus. Forbes. Oct. 13, 2016. URL: https://www.forbes.com/sites/antoinegara/2016/10/13/wall-street-heavyweightgoldman-sachs-launches-its-consumer-lending-platform-marcus/?sh=da93b74628b9

17. Arnold M. European banks to launch blockchain trade finance platform. Financial Times. June 26, 2017. URL: https://www.ft.com/content/6bb4f678-5a8c-11e7-b553-e2df1b0c3220

18. Wigglesworth R., Rennison J. Goldman expands algorithmic corporate bond trading. Financial Times. Aug. 16, 2017. URL: https://www.ft.com/content/6d15c274-70ec-11e7-aca6-c6bd07df1a3c

19. Arnold M., Noonan L. Robots enter investment banks' trading floors. Financial Times. July 07, 2017. URL: https://www.ft.com/content/da7e3ec2-6246-11e7-8814-0ac7eb84e5f1

20. Sadigov E. Professor: The banking system is accelerating the transition to an electronic economy. UNEC News. Dec. 19, 2020. URL: http://news.unec.edu.az/ekspert-reyi/6983-professor-bankovskaya-sistemauskoryaet-perekhod-k-elektronnoj-ekonomike (In Russ.).

21. Mammadov Z. The banking system must be restructured. UNEC News. Dec. 16, 2020. URL: http://news. unec.edu.az/ekspert-reyi/6975-bank-sistemi-yeniden-gurulmalidir (In Azerb.).

\section{ABOUT THE AUTHOR / ИНФОРМАЦИЯ ОБ АВТОРЕ}

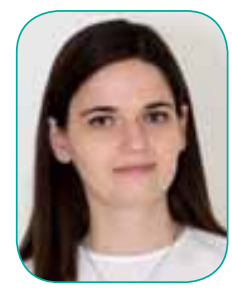

Yegana F. Veliyeva - Cand. Sci. (Econ.), Department of Finance and Financial Institutes, Azerbaijan State University of Economics, Baku, Azerbaijan

Егяна Физули кызы Велиева - кандидат экономических наук, кафедра финансов и финансовых институтов, Азербайджанский государственный экономический университет, Баку, Азербайджан

veliyeva_yegana@bk.ru

The article was submitted on 14.12.2020; revised on 21.12.2020 and accepted for publication on 27.12.2020. The author read and approved the final version of the manuscript.

Статья поступила в редакцию 14.12.2020; после рецензирования 21.12.2020; принята к публикации 27.12.2020. Автор прочитала и одобрила окончательный вариант рукописи. 